\title{
Large numbers of Acropora palmata grow in shallow water in St. John, US Virgin Islands
}

\author{
Peter J Edmunds
}

Department of Biology, California State University, Northridge, California 91330-8303. Email: <peter. edmunds@csun.edus.

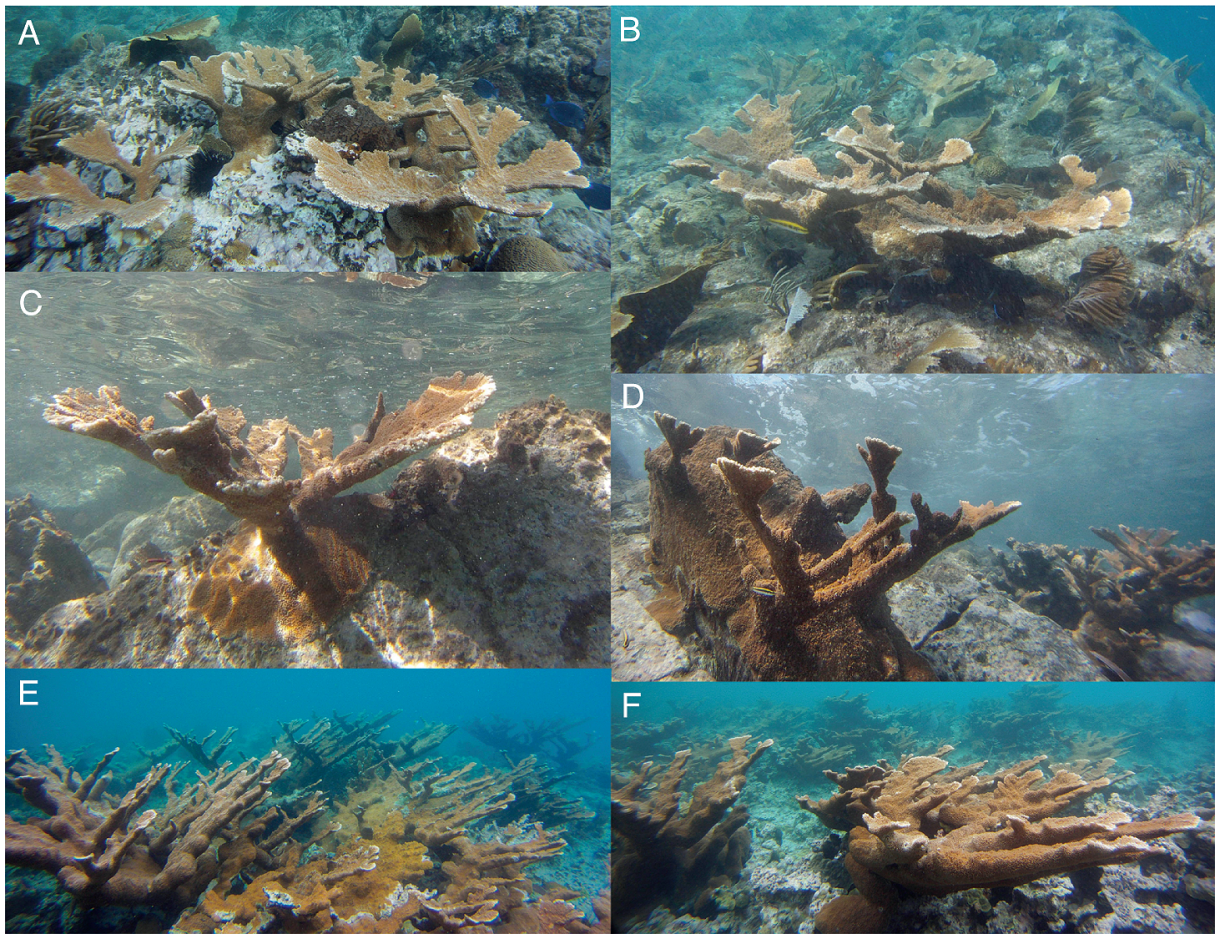

Acropora palmata (Lamarck, 1816) is an iconic coral that was once one of the most important reef builders in the Caribbean Sea. Starting in the early 1980s, A. palmata was decimated by white band disease (WBD) and hurricanes (Aronson and Precht 2001), and in 2006 was listed as threatened under the US endangered species act, where it is now being considered for listing as endangered (Federal Register 77 FR 73219). In the US Virgin Islands, A. palmata was common in the 1970s (Gladfelter 1982, Beets et al. 1986), but in St. John in 1990, following decades of attrition from a variety of agents including WBD and Hurricane Hugo (September 1989), no live colonies of this species could be found in shallow water along $4 \mathrm{~km}$ of the south coast between Cabritte Horn and White Point (PJ Edmunds pers obs). Historically, the shore between these points has provided suitable habitat for A. palmata (Beets et al. 1986). During 2 wks of field work in 1992, when large swaths of the shore between Cabritte Horn and White Point were visited on snorkel and scuba, three colonies of $A$. palmata $(<10$-cm diameter) were seen along the eastern shore of Yawzi Point (which lies between Cabritte Horn and White Point), and in 1999 (also during annual field work) three additional colonies (approximately $75 \mathrm{~cm}$ diameter) were found on the tip of Yawzi Point. In 2003, Grober-Dunsmore et al. (2006) found 398 colonies of A. palmata in 29,251 $\mathrm{m}^{2}$ of shallow ( $<5 \mathrm{~m})$ reef along approximately $1 \mathrm{~km}$ of the sides and tip of Yawzi Point. In 2004, A. palmata at the tip of Yawzi Point occurred at a density of 0.12 colonies $\mathrm{m}^{-2}$, and by 2010 it reached 0.17 colonies $\mathrm{m}^{-2}$ (Muller et al. 2014). 
By March 2014, colonies of $A$ palmata were found along a larger portion of the coast between Cabritte Horn $\left(18^{\circ} 18.450^{\prime} \mathrm{N}, 64^{\circ} 43.297^{\prime} \mathrm{W}\right)$ and White Point $\left(18^{\circ} 18.851^{\prime} \mathrm{N}, 64^{\circ} 43.909^{\prime} \mathrm{W}\right)(\mathrm{A}-\mathrm{D}$ in Figure) than just at Yawzi Point, and within this larger area it was common in shallow water $(<5-\mathrm{m}$ depth). Snorkel surveys were used to estimate the population density of these corals, and were conducted by the author using timed transects along the shore. Markers on the shore were used to note the start and end of each transect, and these were later identified in Google Earth and used to determine the length of the transects with the ruler tool. The length of the transects and the width of the area searched (about $6 \mathrm{~m}$ ) were used to estimate the area searched. These surveys revealed 120 colonies of A. palmata in 20 min of searching along the west of Cabritte Horn, 208 colonies in $37 \mathrm{~min}$ along Yawzi Point, and 102 colonies in 10 min along the east of White Point. Off the north coast of St. John, A. palmata was also common in March 2014 at Waterlemon Cay (130 colonies seen in about $15 \mathrm{~min}$ ) and Hawksnest Bay (300 colonies seen in about $4 \mathrm{~min})\left(18^{\circ} 20.831^{\prime} \mathrm{N}, 64^{\circ} 46.848^{\prime} \mathrm{W}\right.$; E,F in Figure), although both of these locations have had persistent populations of $A$. palmata since at least the 1980s (Beets et al. 1986, Muller et al. 2014).

Together, the present surveys covered approximately 1 ha of reef and the summed abundance of $A$. palmata within this area was equivalent to about 1055 colonies ha ${ }^{-1}$. Between Cabritte Horn and White Point, many colonies were less than about $15-\mathrm{cm}$ diameter, suggesting they appeared on these surfaces within the last 5 yrs if they grew at approximately $3 \mathrm{~cm} \mathrm{yr}^{-1}$ (van Moorsel 1988). In general, it is problematic to infer sexual recruitment from the presence of small colonies of A. palmata (Miller et al. 2007), but in the present case the abundance of large areas of relatively smooth igneous rock on the shallow reefs allows for the unambiguous description of sexual recruits when these appear de novo on igneous surfaces (Edmunds et al. 2011). During surveys for coral recruits (of all taxa) on these surfaces (Edmunds et al. 2011), only seven Acropora recruits ( $\leq 4 \mathrm{~cm}$ diameter) have been recorded in annual surveys at 5-9 m depth since 1994 [80-240 quadrats $(0.5 \times 0.5 \mathrm{~m}) \mathrm{yr}^{-1}, 3040$ in total]. Given the high abundance of $A$. palmata in water $<5 \mathrm{~m}$ depth, both historically in this location (Beets et al. 1986, Grober-Dunsmore et al. 2006) as well as in the present study, it is possible that recruitment of A. palmata on the study reefs remains highest in shallow water (i.e., $<5 \mathrm{~m}$ depth). Although it is statistically equivocal as to whether the A. palmata population around St. John is growing-it significantly increased from 2001 to 2003 (Grober-Dunsmore et al. 2006), but not from 2004 to 2010 (although mean densities were higher in 2010 than 2004 in six of 10 sites; Muller et al. 2014) - the present study suggests population growth along 4 $\mathrm{km}$ of coast between 1990 and 2014.

\section{ACKNOWLEDGMENTS}

This work was funded by the US National Science Foundation (DEB 08-41441 and OCE 13-32915) and was completed under permit VIIS-2013-SCI-0034 from the VI National Park. This is contribution number 216 of the marine biology program of California State University, Northridge.

\section{Literature Cited}

Aronson RB, Precht WF. 2001. White-band disease and the changing face of Caribbean coral reefs. Hydrobiologia. 460:25-38. http:/Tdx.doi.org/10.1023/A:1013103928980

Beets J, Lewand L, Zulto ES. 1986. Marine community description and maps of bays within the Virgin Islands National Park/Biosphere Reserve. VIRMC Biosphere Reserve Research Report No. 2. p. 188.

Edmunds PJ, Ross CLM, Didden C. 2011. High, but localized recruitment of Montastraea annularis complex in St. John, United States Virgin Islands. Coral Reefs. 30:123-130 http://dx.doi.org/10.1007/ s00338-010-0676-4

Gladfelter WB. 1982. White-band disease in Acropora palmata: implications for the structure and growth of shallow reefs. Bull Mar Sci. 32:639-643.

Grober-Dunsmore K, Bonito V, Frazer TK. 2006. Potential inhibitors to recovery of Acropora palmata populations in St. John, US Virgin Islands. Mar Ecol Prog Ser. 321:123-132. http://dx.doi.org/10.3354/ meps321123

Miller MW, Baums IB, Williams DE. 2007. Visual discernment of sexual recruits is not feasible from Acropora palmata. Mar Ecol Prog Ser. 335:227-231. http://dx.doi.org/10.3354/meps335227

van Moorsel GWNM 1988. Early maximum growth of stony corals (Scleractinia) after settlement of artificial substrata on a Caribbean reef. Mar Ecol Prog Ser. 50:127-135. http://dx.doi.org/10.3354/ meps050127

Muller EM, Rogers CS, vanWoesik R. 2014. Early signs of recovery of Acropora palmata in St. John, US Virgin Islands. Mar Biol. 161:359-365. http://dx.doi.org/10.1007/s00227-013-2341-2 